\title{
A SHORT HISTORY OF MICROBIOLOGY IN HUNGARY FROM THE BEGINNING TO 1951*
}

\author{
S. D. KARASSZON \\ Hungarian Society for History of Medicine \\ Török utca 12, H-1023 Budapest, Hungary \\ (Received: April 22, 2001; accepted: May 31, 2001)
}

\section{Introduction}

"On December $27^{\text {th }} 1927$ at a committee meeting of the Royal Society of Natural Sciences, Dr. Hugó Preisz M.D. proposed the foundation of a microbiological section within the Society. He commented that the previous year at an international conference on rabies in Paris, several scientists decided to establish an international microbiological society with the aim of promoting scientific work in each branch of microbiology and fostering friendly relations between scientists working in different countries. The Hungarian microbiologists called together regarding this matter founded the Hungarian Society for Microbiology. They elected retired university Professor Hugó Preisz M.D. president..."

Hugó Preisz M.D. asked whether it would be more reasonable to establish a Microbiological Section, within the framework of the Royal Society of Natural Sciences, instead of an independent Hungarian Society for Microbiology. The committee accepted the suggestion unanimously and elected Aladár Aujeszky M.D. vice-president, Lajos Gózony M.D. secretary and Béla Johan, M.D. and Rezső Manninger D.V.M. editors.

We can learn about the activities of the Microbiological Section of the Society of Natural Sciences from the short reports appeared in the issues of the Bulletin of the Royal Society of Natural Sciences. We know from these short reports that in 1927 seven Hungarian microbiologists participated in a microbiological conference held in

* This paper was written to commemorate to the fiftieth anniversary of the foundation of the Hungarian Society for Microbiology. 
Vienna. These scientists were: László Detre, Béla Fenyvessy, Béla Kanyó, János Köves, Miklós Rohonyi, Lajos Szélyes and Károly Vas.

The following years did not serve to strengthen the newly formed Section. Aujeszky died in 1933 and Preisz in 1940. Some fled abroad from anti-Jewish discrimination, others chose inland seclusion within the country. After the Second World War the class struggle, nationalisation and the complete transformation of our scientific life justified the foundation of a new, independent Hungarian Society for Microbiology. The $50^{\text {th }}$ anniversary would not be complete without mentioning the achievements in microbiological research of outstanding Hungarian scientists in the decades before the foundation on one hand and a re-examination of the foundation year of the Society in relation to its legal continuity.

Institutes of microbiology and famous microbiologists in the decades preceding the establishment of the Society

\section{Institutes}

From the point of view of the development of microbiology in Hungary, the laboratories and institutes, ensuring the provision of the equipment necessary for the cultivation of this special field, are of crucial importance. The most important of them are the many vaccine producing institutes, the first of which, the Smallpox Vaccinations Institute, was opened in 1824 for the purpose of producing vaccine against pox under the direction of Professor Ferenc Xavér Gebhardt. The Pasteur Institute of Budapest, established at the suggestion of Professor Endre Högyes and run by him until his death, is of immense significance from the point of view of both the development of microbiology and the history of national vaccine production. The institute began its activity on April 15, 1890 following order No. 57404 of January 18, 1890 issued by the Ministry of Religion and Public Education.

In the same year when Högyes started the use of vaccine against rabies (1890), István Bethlen, the minister of agriculture, signed an agreement with the director of the Vienna branch of the Pasteur-Chamberland laboratory, as a result of which the laboratory of dubious fame was transferred to Budapest. Control of the vaccine against anthrax and swine erysipelas distributed by the laboratory in our own country was carried out by Professor István Rátz, the director of the Institute of Veterinary Pathological Anatomy. The start of home production of veterinary vaccines is linked to the name of Professor Preisz and is connected with the activity of the Royal Hungarian Institute for Bacteriology founded by him in 1890 . 
As it can be seen from what has been said so far, following the birth of bacteriology, several laboratories of the new science were opened throughout the country; Kálmán Balogh's Institute for General Pathology, Gustav Scheuthauer's Institute for Pathological Anatomy, Fodor's Institute for Public Health within the University and the Metropolitan Institute for Bacteriology. The latter carried out considerable researches and investigations under the direction of Ottó Pertik. The very first institute with national authority and influence was the Royal (State) Hungarian Institute for Bacteriology mentioned above, which was firstly led by Hugo Preisz and later by Aladár Aujeszky. This institute performed the official diagnostic and research tasks relating to microbiological examination until the National Institute for Public Health was opened under the direction of Béla Johan in 1927. Following this model the National Institute for Veterinary Hygiene began its activity in 1929 under Rudolph Manninger's guidance. More and more serum and vaccine producing institutes were established. University clinics, pathological institutes and hospital pathology departments opened microbiological laboratories. Besides, specialists required specific laboratory qualificatons and needed to acquire the necessary microbiological knowledge to become laboratory specialists.

Despite the widespread, successful microbiological activity a long time passed before a department of microbiology was established within a university. It first came into existence at the then Veterinary High School (1907) under the direction of Aladár Aujeszky. At the Medical Faculty of the University of Budapest the Institute for General Pathology and Bacteriology was founded in 1883 under the direction of Professors Endre Hőgyes, Hugó Preisz and later Sándor Belák

After the end of the Second World War, independent medical universities were established with independent microbiological institutes. At the Medical University of Budapest, the name of the former Institute for General Pathology and Bacteriology was renamed the Institute for Bacteriology and Immunology and the gifted Ferenc Faragó was appointed its director. After his tragic death in 1950 the Institute for Microbiology was established under the direction of Professor Zoltán Alföldy (1904-1992) and the institute has been successfully serving medical training needs ever since.

As in the case of the Medical University in Budapest, the Medical Universities of Pécs, Szeged and Debrecen similarly founded a Department of Microbiology under the direction of Professors Béla Fenyvessy, Károly Rauss (Pécs), György Ivánovics (Szeged), Endre Jeney and Lajos Váczi (Debrecen), respectively. Significant microbiological activity was characteristic of the Institutes of Hygiene of the Medical Universities. Their activity, however, belongs to the $2^{\text {nd }}$ phase of the development of microbiology in Hungary. 


\section{Bacteriologists}

Having discussed the birth and development of these microbiological institutions we consider it important to review the names and activities of those Hungarian scientists and researchers who contributed creatively to the universal development of this branch of science and who can rightly be called the Hungarian masters of microbiology. The significance of their activity is increased by the fact that their appearance demanded a new approach not only to medicine but to their way of thinking, which was not received favourably by all members of the scientific community.

They had to continue a difficult struggle with the then fashionable alternative trends. Among these in particular were the followers of homoeopathy, who denied the aetiology of illness and disagreed with the ideas of infection and its role, offering medicine for every illness on the basis of their peculiar system of fallacious notions. The spread of their false doctrines was aided by the cholera situation, against which academic medicine was still helpless. Having the new results of bacteriology accepted in such a situation demanded the energy and charismatic personality of Kálmán Balogh, Professor of Pathology (1835-1888). It was he who under his microscope first observed bacteria in the blood smear of a sheep perished by anthrax (1863). Not only did he become the first enthusiastic follower of bacteriology and the theory of infection, but he also encouraged his colleagues to do microbiological research.

Remarkable bacteriological and parasitological investigations were begun first in Gusztáv Scheuthauer's (1832-1894) Institute of Pathology and later in József Fodor's (1843-1901) Institute of Public Health. This demonstrates the two main trends in the development of microbiology, the pathological and the hygienic directions. The former studied the pathogenic characteristics of microbes from the point of view of pathogenesis of diseases. The latter dealt partly with diagnostic and partly with serum and vaccine producing tasks in order to prevent epidemics.

Joseph FODOR (1843-1901) was the founder of public health research in Hungary, and became the first Professor of hygiene as the pioneer of bacteriological tendency in hygiene. In the 1870s he found that soil is the most abundant in bacteria in its upper layer, and that the decomposition processes in the soil are closely related to bacterial density. During the typhoid epidemic affecting the town of Pécs in 1890, he found the source of infection in the sewage oozing from the privy of the hospital laundry into the trunk line of the water supply. Studying the bacterium-filtering ability of the soil, he searched for possibilities of accidental bacterial contamination of dug wells. He constructed equipment suitable for lifting out samples from different depths for bacteriological examination, and another apparatus, the so-called "bacteriumfishing" one (later regarded as an ancestor of the micromanipulator) for the isolation of 
bacterial colonies and production of pure cultures. He showed in 1886 that, due to the bactericidal action of blood, bacteria injected into the blood of experimental animals were quickly decomposed there. For this last discovery he is regarded as the first immunologist, the discoverer of humoral immunity.

Victor BABES (1854-1926) Rumanian microbiologist, founder of Rumanian microbiology, began his professional career in Scheuthauer's Institute of Pathological Anatomy. He wrote a number of publications in Hungarian, for example the first textbook of Bacteriology (1886). Rumanian authorities, taking note of his valuable research work (i.e. on Corynebacteria) performed in Budapest, invited him to continue the microbiological research in Bucharest, Rumania. His successful achievements are of essential importance.

Hugó PREISZ (1860-1940) was the founder and first Director (1890) of The Royal State Institute of Bacteriology in Budapest, Hungary. He soon became the first Professor of General Pathology and Bacteriology at the Faculty of Medicine of Budapest University. He was interested in practical bacteriological diagnostics, vaccine production and control. He was the first to initiate research on theoretical questions of immunology. Using intradermal injections he studied virulence of swine erysipelas bacteria, a species that had been discovered by Loeffler two years earlier. The method developed by him became widely accepted on the basis of the publication of his coworkers FORTNER and DINTER (1944). He revealed that strains of the causative agent of swine erysipelas that had lost virulence due to in vitro passages regained virulence while passaged in pigeons. He discovered Corynebacterium ovis called Bacillus Preisz-Nocard for a long time. He also worked with the bacteria called Yersinia today. The experience at his plague laboratory helped to stop the panic that had broken out in Fiume because of plague-suspect cases observed in 1901. The discovery that virulence of Bacillus anthracis is associated with the capsule-producing capacity of the strains was of outstanding importance. His results on the $\mathrm{S} / \mathrm{R}$ variation of Bacilli founded an international school of microbiology with the participation of Joseph TOMCSIK and György IVANOVICS in Hungary, and many other colleagues abroad. He also worked with Brucella strains. He developed the Preisz' pyrogallic acid procedure for the cultivation of bacteria under anaerobic conditions. He contributed to the discovery of Brucella suis by Ferenc HUTYRA and Árpád MARCIS differentiating it from Brucella abortus, to the recognition of the human pathogenicity of Mycobacterium bovis recognizing the bacterium contamination of commercial milk products. His work on bacteriophages will be mentioned below.

Aladár AUJESZKY (1869-1933) was the successor of Preisz as Director of the Royal State Institute of Bacteriology. He was elected Professor of Bacteriology of the Veterinary High School of Budapest. He had innovative results on tuberculosis, 
malleus, fowl typhoid, anthrax and staphylococcus bacteria. His most important discovery was in the field of virology, which will be mentioned later.

László DETRE (1874-1939) invented the word "antigen". He was Director of the Jenner-Pasteur Laboratory (1901-1918) and of the "Hungarian Serum Works". He became senior lecturer at the University later. He discovered the bacterium now called Clostridium perfringens variant $\mathrm{C}$. He succeeded in differentiating the infection of this bacterium called by him "Bacillus zoodysenteriae (Hungaricus)" from the clinical picture of coli dysentery.

Gyula DARÁNYI (1888-1958) was the Professor of Hygiene at the Faculty of Medicine of Budapest University. He worked with Staphylococci, Mycobacteria, and on the thermoresistance of bacteria. He wrote an outstanding handbook of hygiene including the $3^{\text {rd }}$ volume on bacteriology.

Rezső MANNINGER (1890-1970). Professor of Epidemiology and Microbiology at the University of Veterinary Science, Budapest. He was an important member of the Hungarian school of microbiology research. He discovered many properties of the virulence of Pasteurella strains, contributed to the development of swine erysipelas vaccine strains, and to the typing and taxonomy of Salmonella isolates, he transformed successfully Bacillus strains with the DNA of capsule-producing strains of Bacillus anthracis in 1962.

István LOVREKOVICH (1895-1960) was the main organizer of the department of Bacteriology at the National Institute of Public Health, Budapest in 1927 financed by The Rockefeller Foundation. He developed a bismuth-sulphite-agar for the differential diagnostics of Salmonella typhi. Using this medium, he raised typhoid diagnostics to an outstandingly high level. In cooperation with Károly RAUSS he developed a typhoid vaccine of high efficacy. After World War II he worked in a Hungarian pharmaceutical factory. He initiated Hungarian streptomycin production, and performed successful investigations into other antibiotics.

Ferenc FARAGÓ (1905-1950). Professor and director of the first chair and Institute for Bacteriology and Immunology - in collaboration with his master Joseph TOMCSIK (1898-1964) - achieved considerable success by vaccination against diphtheria. The "depot" method raised satisfactory immunity in a single inoculum. He produced also considerable results in the field of immunization against pertussis and scarlet fever. He died in 1950 as a victim of a political made-up charge.

Zoltán ALFÖLDY (1904-1992). Professor of Microbiology of the Semmelweis University School of Medicine, Budapest, initiated the research on Leptospira in Hungary in 1947 with the gropu led by him. It has to be mentioned that thousands of Hungarian medical students were taught using the Textbook of Microbiology written by him with his co-authors. 


\section{Rickettsia researchers}

Rickettsia research in Hungary served the purpose of vaccine production against exanthematous typhus. In the beginning body lice were used for the propagation of pathogens. The parasitologist Ferdinand Ziegler (Nándor Zoltai) excelled in this work. Later Elek Farkas and his co-workers succeeded in adapting the Matelska-strains brought from Berlin to embryonated hen's eggs. Due to the administration of the Coxtype vaccine produced in this way, our country remained free from the exanthematous typhus, a frequent concomitant of war.

\section{Food microbiologists}

In the field of bacteriological meat-inspection Albert Breuer (1870-1930) and Géza Semsey (1894-1947) and in the field of microbilological examination of milk Ottó Fettick gained the greatest distinction.

\section{Plant microbiologists}

The activity of the high school chemistry teacher Mór Preys (1829-1877) is of significance, not only from the point of view of the history of Hungarian microbiology, but also from that of universal microbiology. In 1861 at almost the same time as Pasteur, but independently, he described the possible conservation of wine by heating.

Mention must be made of the great achievements such as

Gyula Istvánffy showed great merit in the investigation of the diseases of grape vines.

Károly Schilberszky (1863-1933), Károly Vas (1884-1948) and László Beke (1881-1950) were prominent in the study and explanation of the aetiology of the potato and other plant diseases.

Dániel Fehér (1891-1955) distinguished himself in the field of soil bacteriology.

\section{Virologists}

In the struggle against diseases of viral origin, János BÓKAY JR., professor of pediatrics (1858-1937) distinguished himself at a very early stage. In 1892 he observed the similarities, moreover identity of varicella (chickenpox) and herpes zoster (shingles).

Endre HŐGYES (1847-1906), Professor of General Pathology at Budapest University, established the Institute Pasteur of Budapest and he was the first Director of that institute. He developed and characterized a new, original fixed virus strain of rabies virus and found the strain highly suitable for vaccine production. Furthermore, he introduced a so-called "dilution" technique, which proved to be preferable to Pasteur's method based on exsiccation of spinal cords. His successful investigations were supported by his inventive and ambitious co-worker, József LŐTE (1856-1938). 
Aladár AUJESZKY (see above) was another successful pupil of Endre HÖGYES. He discovered a form of encephalitis now called "Aujeszky disease" (he used the designation "pseudorabies"") (1902). He isolated the virus of the disease and described some of its properties. These investigations added considerable data to the differential characterisation of the fixed virus of rabies and its differentiation from the street virus.

The swine plague ravaging in Hungary at that time prompted Ferenc HUTYRA (1860-1934), Professor of Epidemiology at the Veterinary High School, to establish a virus research laboratory in which he and his co-worker, János KÖVES (1882-1977) isolated the pathogen of the disease. They characterized the virus biologically and developed an immunisation method, which was applied successfully to the control of swine plague for many years. Their so-called "simultaneous" method of immunisation was taken over by a number of countries.

It was in 1907 that József MAREK (1868-1952), Professor of Internal Medicine of the Veterinary High School, Budapest, discovered the viral neuromyelomatosis of hens, now called "Marek's disease"; he infected hens with the virus successfully.

As to the investigations into the cytopathogenicity of viruses, György IVANOVICS (see above) and the American, HYDE used micromorphological changes of cells as indicators of in vitro virus infection at a very early time (1936); Rezső MANNINGER and Ferenc LÁSZLÓ (1930) reported on genetic changes in the footand-mouth disease virus while Rezső MANNINGER, József CSONTOS and Gyula SÁLYI (1939) isolated the suipox virus and proved its independence. Rezső MANNINGER and József CSONTOS (1940) proved the identity of the virus of catharrhal influenza of horses with that of "viral abortion". György IVÁNOVICS and his co-workers reported on the cyclic reproduction of the Aujeszky virus.

Among the other masters of virology, Károly JÁRMAI (1887-1941) and Gyula TAKÁTSY (1914-1980) deserve special attention; both devoted their whole scientific activity to virus research.

Károly JÁRMAI, Professor of Pathological Anatomy at the Veterinary High School, Budapest, published considerable results on the viruses of bovine papillomatosis, fowl sarcoma and other transferable tumour viruses. His investigations into fowl leukoses were of special importance. His research fundamentally contributed to the differentiation and biological characterization of the viruses causing lymphogenous and myelogenous leukosis as well as erythroleukosis of the fowl.

To make Gyula TAKÁTSY's merits easier to understand, let us outline the history of influenza research in Hungary from virological aspects. 
After the early attempts of Lajos FEJES ( 1919) to infect monkeys with the hypothetic virus, the pathologist E. BALOGH proclaimed the viral aetiology of influenza on the basis of his own research (1922-1942). In the mid-thirties, the Rockefeller Foundation established an influenza research laboratory with the American Richard M. TAYLOR (1887-1981) as leader, in the National Institute of Hygiene, Budapest. Soon the first influenza virus strain from Central Europe was isolated (R. Taylor and M. Dreguss, 1936); the susceptibility of Cricetus cricetus was proved (Taylor and Dreguss, 1940) and the antigenic effect of the virus was measured (Dreguss, 1940) in the same laboratory. M. Dreguss and Ferenc Hoffmann ( 1941 ) succeeded in immunizing domestic pigs, then M. Dreguss, Árpád Hegyeli and József Szathmáry (1943) reported on natural infection of pigs with the human influenza virus.

The influenza virus research was strikingly promoted, at first in Hungary, then all over the world, by the use of the Microtitrator Set, which was developed by Gyula TAKÁTSY in 1949 and published in the early 1950s (J. Takátsy, 1950, 1952, 1955). The set has been advantageously applied not only in virology but also in microtechniques necessary in many other branches of science; both in research and practice. In the National Institute of Hygiene, researchers at the Department of Virology soon isolated and characterized influenza virus strains of different serotypes. A fruitful collaboration was built up with the World Influenza Centre, London. Julius Takátsy studied the role of antigen variants in epidemics thoroughly and developed a simple new method for purification and concentration of influenza virus (1954) and applied his micromethods in developing a serum-absorption test aimed at analysing the antigens of different strains with high accuracy. He extended his research to the ecology of influenza virus and developed a method suitable for mass production of influenza vaccine even in poor countries; he followed the efficiency of mass vaccination using his simple methods.

\section{Phage researchers}

At the top of the list of Hungarian phage researchers the name of Hugó PREISZ is to be found again (see above). He initiated investigations soon after d'Herelle's discovery (1917) and supported the virus theory of phages definitely. In reports dealing with the so-called Pettenkoferia he distinguished the microorganisms from phages. He summarized his phage research in a monograph. Phage typing of bacterial strains started in the National Institute of Hygiene in a laboratory headed by Mária EÖRSI (1948).

\section{An investigator of Chlamydia}

Miklós MELCZER (1891-1985), Professor of Dermatology and Venereal Diseases first at the Faculty of Medicine the University of Szeged, later Pécs, 
investigated the aetiology of lymphogranuloma venereum, applying Loeffler's method and later, successfully, the Herzberg method. He reported on intracellular cumulative location of the pathogen. These investigations were performed as early as 1934, i.e. before Tamura (1935) and Miyagawa (1935) reported on the discovery of the pathogen. For this reason, Melczer's results were called into doubt, even in his home country, and the pathogen was given the name Miyagawanella (present name: Chlamydia). In a monograph (1983), Melczer summarized the biological - including microscopical and cultural - characteristics of the pathogen, its animal pathogenicity, etc.

\section{Mycologists}

On the top of the world list of medical mycologists two investigators of Hungarian origin are to be found. These are Dávid GRUBY (1810-1898) and Lajos MANDL (1812-1881). Both lived in Paris.

Dávid GRUBY together with Lajos Mandl as helpmate constructed a microphotographic equipment to his microscope, thus he can be regarded as the inventor of microphotography, which was also popularized by him. Among pathogenic fungi, Achorion, Trichophyton, Microsporon, Oidium and Streptothrix were discovered and described by Dávid Gruby. Moreover, he described the clinical pictures caused by fungi, created nosological groups and gave them definitive names, thus stressing their specificity.

Gruby's epoch-making discoveries became widely known only after Sabouraud's publications. In Lajos NÉKÁM's dermatological clinic, wide-range mycological activities were in course with the leadership of Ede NEUBER and later BALLAGI. In an excellent monograph written by BALLAGI (1929), the whole scope of contemporary medical mycology is included.

With endogenous (systemic) mycoses mainly pathologists were dealt with initially, first of all from diagnostic, pathogenetic, pathologic and pathohistological aspects. Mycology got a new impulse in Hungary when, soon after the end of World War II Béla JOHAN (1889-1983) was charged with initiation of penicillin production. Not much later (1955), a mycological laboratory was established in the National Institute of Hygiene. Then, after the importance of mycotoxicoses had been recognized, research was initiated in order to clarify the corresponding clinical pictures. 


\section{Protozoologists}

In the list of Hungarian protozoologists, Dávid GRUBY was also the first; he discovered the protozoon parasite Trypanosoma sanguinis (1842). Géza ENTZ (18421919) presented another discovery of great importance: he was the first to report that protozoa and algae were living together (1875). It had long been known that some protozoa contained formations that were generally thought to be chlorophyll granules. ENTZ discovered that the granules were, in fact, algae. Later, this sort of copartnership was designated as symbiosis by the German investigator BRANDT (1981). By his discovery, Entz elucidated the way towards recognition of intracellular parasitism.

The Rumanian microbiologist, Victor BABES, at that time Professor in Hungary (see above) made a rather notable discovery in protozoology.. He was requested by the Romanian authorities to study the epizootic haemoglobinuria of sheep grazing in territories exposed to swellings of the Danube, where $20 \%$ of the sheep had died of disease. Babes (1888) found parasitic protozoa in the erythrocytes of sick sheep. Later, he elucidated its intracellular parasitism, and pathogenicity. His priority was recognized by the designation of the parasite: family of Babesia.

István RÁTZ (1860-1917), Professor of Pathological Anatomy at the Veterinary High School, Budapest, was the promoter of parasitology in Hungary and its outstanding cultivator even in international relation. His Sarcosporidium studies deserve special interest; in his reports, two parasitic protozoa are described and their taxonomic place is presented.

Miklós JANCSÓ (1868-1950), Professor of Internal Medicine at the Faculty of "Medicine of the Ferenc József University (Szeged), became famous mainly because of his malaria research. He studied among other things the development of malaria plasmoida in the mosquito and determined the effect of temperature on different developmental stages.

Ferenc LŐRINCZ (1898-1986), the organiser and first leader of the Department of Parasitology of the National Institute of Hygiene also owed his reputation first of all to malaria research. He was very active in the eradication programme.

Sándor KOTLÁN (1887-1967), Professor of Parasitology at the Veterinary High School, a world-famous parasitologist, deserved the title "master of Hungarian parasitology" by the discovery of numerous protozoon species. He described previously unknown Eimeria species living in sheep, rabbits and geese; he clarified the course of endogenic development of numerous Eimeria species with special regard to globidium schizogeny. He resolved some aetiological and vector problems of pyroplasmosis. The 
Coccidium research initiated by KOTLAN was continued by László PELLÉRDY (1907-1974).

Hungarian microbiologists had to face the difficulties presented by two world wars. Hungarian microbiologists still had a significant effect in the fields of research and education at home and abroad. As a result of their hard work the independent Hungarian Society for Microbiology was founded in 1951 under the presidency of András Havas.

\section{Selected original handbooks, textbooks and practical manuals of microbiology from Hungarian authors in this period}

1. Babes, V.: A bakteriológia rövid tankönyve. (Short textbook of bacteriology) Magyar Orvosi Könyvkiadó Társulat, Budapest, 1886.

2. Hutyra, F.: A háziállatok fertőző betegségeinek oktana. (Infectious diseases of domestic animals) Atheneum, Budapest, 1888 .

3. Tangl, F.: Útmutató a bakteriológiában. (Guidebook of bacteriology) Dobrowsky és Franke, Budapest, 1894.

4. Tangl, F.: Bakteriológia. (Bacteriology) In: Tausz, F. (ed.): Klinikai diagnosztika (Clinical diagnostics) II. pp. 469-544. Dobrowsky és Franke, Budapest, 1894.

5. Preisz, H.: Bakteriológia. (Bacteriology) Magyar Országos Állatorvos Egyesület, Budapest, 1899.

6. Pertik, O.: Bevezetés a fertőző betegségek kóroktanába bakteriológiai szempontból. (Pathogenesis of bacterial diseases) In: Bókai- Kétli- Korányi: A belgyógyászat kézikönyve (Manual of internal medicine) I. pp. 1- 98. Magyar Orvosi Könyvkiadó Társulat, Budapest, 1894.

7. Udránszky, L.: A baktériumok chémiai terményeinek szerepe a fertőző betegségeknél. (Bacterial products in infectious diseases) In: Bókai- Kétli- Korányi: A Belgyógyászat Kézikönyve (Manual of Internal Medicine) I. pp. 95- 136. Magyar Orvosi Könyvkiadó Társulat, Budapest, 1894.

8. Hőgyes, A.: Lyssa. (Rabies) In: Nothnagel (ed.): Spec. Pathol. u. Therapie, Bd. V. Teil V. Zoonosen (Zoonoses) II. Abth., Hölder, Wien, 1897

9. Kaiser, K: A bakteriológia rövid tankönyve. (Short textbook of bacteriology) Dobrowsky és Franke, Budapest, 1899.

10. Rigler, G.: Közegészségtan és a fertőzö betegségek (Hygiene and infectious diseases) II. kötet. Kolozsvár, 1910.

11. Aujeszky, A.: A baktériumok természetrajza. (Natural history of bacteria) Királyi Magyar Természettudományi Társulat, Budapest, 1912.

12. Aujeszky, A.: Általános bakteriológia. (General bacteriology) Kir. M. Természettud. Társ. Budapest, 1924.

13. Gózony, L., Lénárd, V.: A gyakorlati bakteriológia zsebkönyve. (Pocket handbook of practical bacteriology) Érseki Lyc., Eger, 1913.

14. Ballagi, I.: Börgyógyászati mykológia. (Dermatomycoses) Magyar Orvosi Könyvkiadó Társulat, Budapest, 1920. 
15. Baló, J.: A láthatatlan kórokozók, filtrálható vírusok. (Invisible agents, filtrable viruses) Magyar Orvosi Könyvkiadó Társulat, Budapest, 1931.

16. Lovrekovich, I., Tocsik, J., Lőrincz, F.: Bakteriológia, immunitástan és parazitológia. (Bacteriology, immunology and parasitology) Magyar Orvosi Könyvkiadó Társulat, Budapest, 1935.

17. Melczer, M.: A negyedik nemi betegség. (The fourth sexual disease) Magyar Orvosi Könyvkiadó Társulat, Budapest, 1938.

18. Lörincz, F.: A maláriáról. (Malaria) Magyar Orvosi Könyvkiadó Társulat, Budapest, 1939.

19. Darányi, Gy.: Közegészségtan (Hygiene) III. Magyar Orvosi Könyvkiadó Társulat, Budapest, 1940.

20. Láng, S.: Bakteriológiai és serológiai vizsgálatok. (Bacteriological and serological tests) Novák R. Budapest, 1941.

21. Kotlán, S.: Parazitológia. (Parasitology) Magyar Országos Állatorvos Egyesület, Budapest, 1944.

22. Faragó, F.: Bakteriológia és immunitástan. (Bacteriology and immunology) Magyar Orvosi Könyvkiadó Társulat, Budapest, 1948. 